\title{
The Impact of Grazing Systems on the Mag- nitude and Stability of Ranch Income in the Rolling Plains of Texas
}

\author{
R.E. WHITSON, R.K. HEITSCHMIDT, M.M. KOTHMANN, AND G.K. LUNDGREN
}

\begin{abstract}
Results of a 1961-1974 grazing system study on the Texas Experimental Ranch in the Rolling Plains were used to evaluate annual net income stability characteristics for a cow-calf operation. A linear programming risk analysis model was utilized to select optimal combinations of grazing systems which minimized annual negative net income fluctuations. Greatest annual net incomes, expressed in 1979 dollars, were obtained from heavier stocked, continuously grazed systems which received winter feed. For the 1961-1974 period, annual net income stability was not increased by selecting combination of grazing systems. However, when only the last 5 years were included in the analysis, the stability of annual net income was improved by selecting a combination of grazing systems. Supplemental winter feeding did not have a significant effect on annual net incomes. However, under heavier stocking rates the standard deviation of annual net income was approximately doubled when cows did not receive supplemental winter feed. Annual income and income variability was determined to have increased during the last 5 years of the study, relative to the total study period. It is hypothesized that a portion of this increased variability at the heavier rates of stocking is the result of changes in the composition of vegetation. The general increase in variability across all systems indicates that ranch operators may need to consider alternatives for risk management as well as management for profits.
\end{abstract}

Ranch operators have long strived to become more efficient in the management of their ranch resources. This effort has been made in order to increase economic returns and reduce economic risks associated with ranching. Risks in the ranching industry are as a result of the nature of livestock market, weather, diseases, prices paid for inputs, the use of credit, and government regulation. In the Rolling Plains of Texas, and in the Great Plains in general, the need to reduce adverse economic impacts of fluctuating forage supplies has resulted in considerable research efforts by public institutions and agencies. A major goal of range research is to identify alternatives to more efficient harvest forage from rangeland and to increase forage quantity and quality for use by domestic livestock. The major purpose of this study was to evaluate net returns and the annual stability of these net returns from five grazing management systems in the Rolling Plains of Texas from 1961 to 1974 (Fig. 1).

In developing a ranch management plan, it is assumed that net income levels and net income stability (risk) associated with various production strategies for inc reasing net income are of concern to ranch operators (Markowitz 1959). Agricultural firm managers

The authors are associate professor, Department of Range Science and Agricultural Economics; assistant professor, Agr. Exp. Sta., Vernon, Texas; professor, Department of Range Science; and research associate, Departments of Range Science and Agricultural Economics, Texas A\&M University, College Station, Texas 77843 .

The authors express appreciation to the Texas Experimental Ranch Committee and Swenson Land and Cattle Company for their support and contributions of time, money, and materials which made this research possible.

Approved by the Direcior, Texas Agricultural Experiment Station as TA-

Manuscript received February 23, 1981.

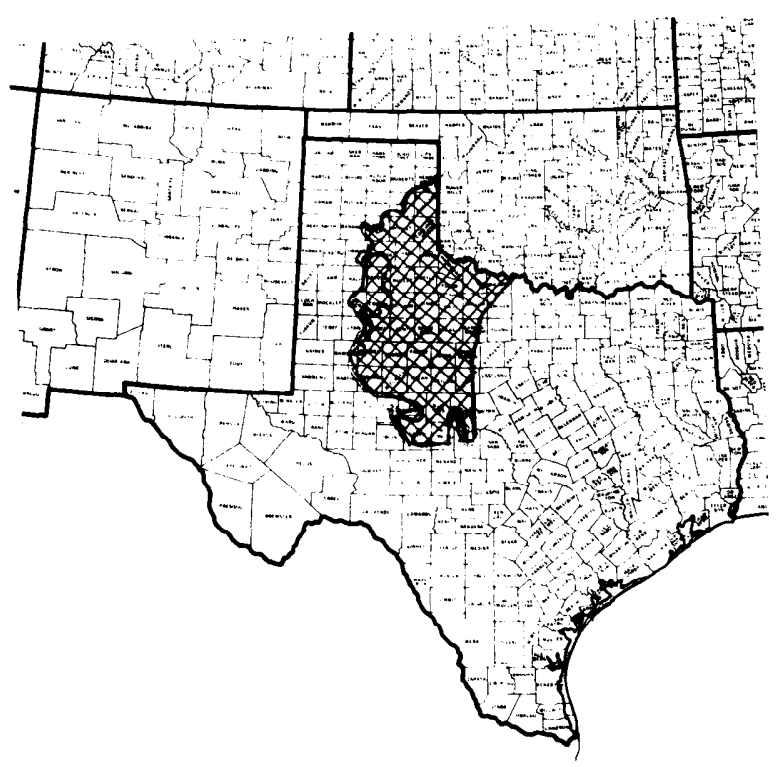

Fig. 1. Study area, economic evaluation of grazing systems in the Texas Rolling Plains, 1961-1974.

typically resort to minimizing or reducing risk by diversification, maintaining flexibility in their operations, and holding reserves of credit or cash (Hopkin et al. 1973).

Traditionally, economic stability has not been included in economic analysis of grazing systems. Economic emphasis has been placed on the identification of net income potential of alternative grazing systems (Kothmann et al. 1971, Merrill et al. 1975, Reardon and Whitson 1980). While this approach is not incorrect, it inherently implies that the ranch operator is primarily concerned with a single objective, maximization of profits.

Kothmann et al. (1970) determined that average return to management and capital to be 1.39 times greater per hectare for heavily stocked, year-long continuous grazing than from a four-pasture, deferred-rotation system at the Texas Experimental Ranch in the Rolling Plains of Texas. For moderate stocking rates, the fourpasture system produced 1.26 times greater average net returns per hectare than a continuous, yearlong grazing system. Since average annual rainfall was generally above the long-term average during the 8 years of the study, the authors hypothesized that stocking rates were generally insufficient to be representative of the intended grazing treatments. Further, it could be expected that in "typical" rainfall periods the economic advantage of the heavier stocking rates would be lost. Variability of annual income was not included in the economic analysis (Kothmann et al. 1970).

Whitson (1975) evaluated alternative grazing management systems in combination with other livestock production/marketing 
Table 1. Average annual gross sales, production costs, and net returns (\$/ha) for five graxing systems on the Texas Rolling Plains, $1961-1974$.

\begin{tabular}{|c|c|c|c|c|c|c|}
\hline \multirow[b]{2}{*}{ Grazing systems } & \multirow{2}{*}{$\begin{array}{l}\text { Actual gross } \\
\text { sales }\end{array}$} & \multicolumn{3}{|c|}{ Actual production costs } & \multirow{2}{*}{$\begin{array}{l}\text { Actual net } \\
\text { returns }\end{array}$} & \multirow{2}{*}{$\begin{array}{l}\text { Net returns } \\
\text { expressed in } \\
1979 \text { dollars }\end{array}$} \\
\hline & & Variable & Fixed & Total & & \\
\hline $\begin{array}{l}\text { Supplemental feed } \\
\text { Heavy, continuous } \\
\text { Moderate, continuous } \\
\text { Moderate, 4-pasture }\end{array}$ & $\begin{array}{l}20.75 \\
14.06 \\
15.64\end{array}$ & $\begin{array}{l}4.35 \\
2.87 \\
2.89\end{array}$ & $\begin{array}{l}3.26 \\
2.22 \\
2.33\end{array}$ & $\begin{array}{l}7.61 \\
5.09 \\
5.22\end{array}$ & $\begin{array}{r}13.14 \\
8.97 \\
10.42\end{array}$ & $\begin{array}{l}28.53 c \\
19.17 d \\
22.45 d\end{array}$ \\
\hline $\begin{array}{l}\text { No supplemental feed } \\
\text { Heavy, continuous } \\
\text { Moderate, continuous }\end{array}$ & $\begin{array}{l}19.81 \\
13.95\end{array}$ & $\begin{array}{l}3.93 \\
2.52\end{array}$ & $\begin{array}{l}3.21 \\
2.20\end{array}$ & $\begin{array}{l}7.14 \\
4.72\end{array}$ & $\begin{array}{r}12.67 \\
9.23\end{array}$ & $\begin{array}{l}27.22 \mathrm{c} \\
19.83 \mathrm{~d}\end{array}$ \\
\hline
\end{tabular}

'Annual net returns to land and management.

${ }_{2}$ The wholesale price index was utilized to express the time series in 1979 dollars. Means followed by the same letter are not significantly (.05) different.

alternatives for risk-return characteristics of a ranch firm in the Rolling Plains of Texas. Alternative ranch organizations were identified which produced annual gross margins ranging from $\$ 21.09 /$ ha to $\$ 38.08 /$ ha. Standard deviation of these respective mean net incomes ranged from $\$ 1.70 /$ ha to $\$ 23.41 /$ ha. Grazing systems, for the period 1969-1973, were determined to produce different mean incomes which had differing income stability characteristics. A moderately stocked four-pasture, deferred-rotation system (Merrill 1954) produced the most stable net income. However, continuous, yearlong grazing at a heavier rate of stocking produced the greatest average annual income, especially when weaned calves were retained for further weight gain. The study indicated ranch operators could be "optimally" organized and not have the same ranch plan, depending upon risk-return preferences.

Economic analysis of grazing systems in the Edwards Plateau region of Texas indicated that for similar rates of stocking, twoand four-pasture rotation systems produced highest average net returns as well as the most stable returns over a 7-year study period. Stability of these systems was attributed to availability of a forage reserve, greater plant vigor, and multiple use of forage by sheep and cattle (Huss and Allen 1969).

Preliminary economic studies of grazing systems in the Rio Grande Plains of Texas indicate that a short duration system (one herd, six pastures) produced the largest average net income/hectare when contrasted to yearlong continuous or a four-pasture, deferred-rotation system (Reardon and Whitson 1980). The fourpasture system was economically superior to the yearlong system, but the analysis did not include stability characteristics.

\section{Procedures}

Annual costs and returns were budgeted for five alternative grazing systems which were evaluated on the Texas Experimental Ranch near Throckmorton, Texas, for the period 1961 through 1974. A sixth treatment, a four-pasture deferred-rotation system without supplemental feed was initiated in 1970. The grazing systems included moderate (MC) and heavy yearlong continuous (HC) grazing (with (S) and without supplemental winter feeding) and a moderately stocked four-pasture deferred-rotation system with supplemental winter feeding (M4PS). A moderately stocked four-pasture system without winter feeding was initiated in 1970 (M4P). A cow-calf operation was used for all systems with weaned calves being sold in the fall. Percent calf crop, weaning weights and annual stocking rates were those encountered during the study as reported by Heitschmidt et al. (1980). Minor adjustments in stocking rates within any given year were considered in this analysis by assessing a feed cost (hay) for cows which were removed for relatively short time periods (6 months or less) from any given treatment. Annual net returns to land and management were estimated for 1961 through 1974.

Annual market prices for each year of the study (USDA 1974), were utilized to determine the value of cull cows, weaned heifers, weaned steers, and culled replacement heifers produced from each grazing system. Annual variable costs, for winter supplemental feed, medicine, salt and minerals, transportation, labor, market- ing, repairs, gas, oil lubricants, and interest on annual operating capital were estimated from annual livestock budgets and available statistical series (USDA 1978, USDA 1980, Texas Agricultural Extension Service 1980). These budgets were adjusted for actual costs and input quantities when data were available. Annual variable costs, not available from historical records were adjusted to a specific year by utilizing the index, "Prices paid by farmers" (USDA 1975, USDA 1979).

Annual fixed costs associated with each grazing system included an opport unity cost on the annual capital invested (annual salvage value) in the breeding herd, in facilities and equipment, and annual depreciation. All cows and equipment were assumed to be debt free. The opportunity cost of capital which varied as a result of economic conditions was estimated to be $2 \%$ less than the cost of borrowed capital from an agricultural lending institutions (USDA 1980). Annual net returns to land and management were calculated by subtracting variable and specified fixed costs from gross livestock sales. In order to eliminate the impact of inflation over time, the annual net returns were converted to 1979 dollars using a wholesale price index (US Dep. Commerce 1979).

The number of producing cow units associated with each grazing system was adjusted to account for replacement animals, horses, and bulls when they were not with the herd.' For the study, it was estimated that one mature cow plus requirements for replacement females, bulls, and horses, amounted to $15.6 \mathrm{AUM} /$ year.

For a given average net income level, minimum income variability was determined by use of a linear programming (LP), riskreturn model described by Hazell (1971). The model was specified to minimized total negative deviations (MOTAD) from average net income associated with each grazing system. positive deviations in income were assumed to cause fewer economic problems than negative deviations for ranch operators in the Rolling Plains. The use of the MOTAD model further implied the negative deviations of annual net income represented a reasonable estimate of risk; i.e., stability of income.

The principal advantage of the use of a risk-return model was that given the results of the analysis, the opportunity existed to incorporate variability of income as well as the magnitude of net income associated with a given strategy (Whitson 1975).

\section{Results and Discussion}

\section{Economic responses $-1961-1974$}

Gross livestock sales ( $\$ /$ ha) included the influence of the livestock price cycle as well as beef cattle production associated with five alternative grazing systems in the Rolling Plains (Heitschmidt et al. 1980). Actual annual gross sales, production costs, and net returns/ha are illustrated for each grazing system in Figures 2, 3, and 4 , respectively.

Except for 1974, actual gross sales/ha increased at a relatively

\footnotetext{
IReplacement females were not actually maintained on the Experimental Ranch, but were available as required from off station sources. Thus, in order to more nearly approximate "typical" ranching operations replacement breeding stock, horses, and the portion of the year that bulls were not included with the herd were included in the ranch inventory to reflect total forage requirements associated with each grazing systems.
} 


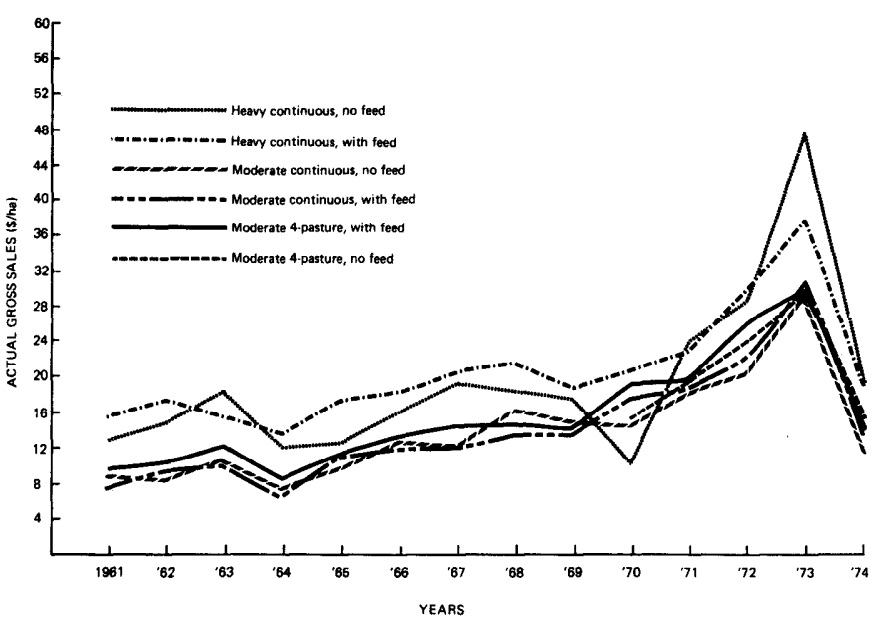

Fig. 2. Actual gross sales (\$/ha) from alternative grazing systems on the Texas Experimental Ranch, 1961-1974.

consistent rate across all systems from year to year other than the heavily stocked, continuously grazed system, which received no supplemental winter feed (Fig. 2). Actual total production costs/ha were also relatively consistent from year to year with costs generally increasing over time for all systems. The major exception to this finding was the $\mathrm{HC}$ system, which began to experience greater annual fluctuations in 1968 when compared to other systems (Fig. 3).

Actual net returns/ha tended to increase over time but with relatively larger annual fluctuations than were observed with gross sales and costs (Fig. 4). Year to year variability became more apparent when net returns were expressed in 1979 dollars, eliminating the impact of inflation (Fig 5). However, considerable net income variability was present in all grazing systems evaluated in this study. The variability in annual net income ranking among systems, was primarily the result of annual variability in livestock performance since livestock sales prices were relatively constant across systems for any given year (Fig. 5).

There was considerably more economic instability for the period 1970 through 1974 when net income was expressed in 1979 dollars. For example, annual net returns from the $\mathrm{HC}$ system ranged from approximately $\$ 7.00 /$ ha to $\$ 58.00 /$ ha from 1970 through 1974 . For the period 1961 through 1969 , the HC system ranged from $\$ 18.00$ / ha to $\$ 36.00 /$ ha (Fig. 5).

Relative positions among the grazing systems varied from year to year relative to average annual gross sales, costs and net returns for actual and 1979 dollars (Table 1). The heavier stocked systems

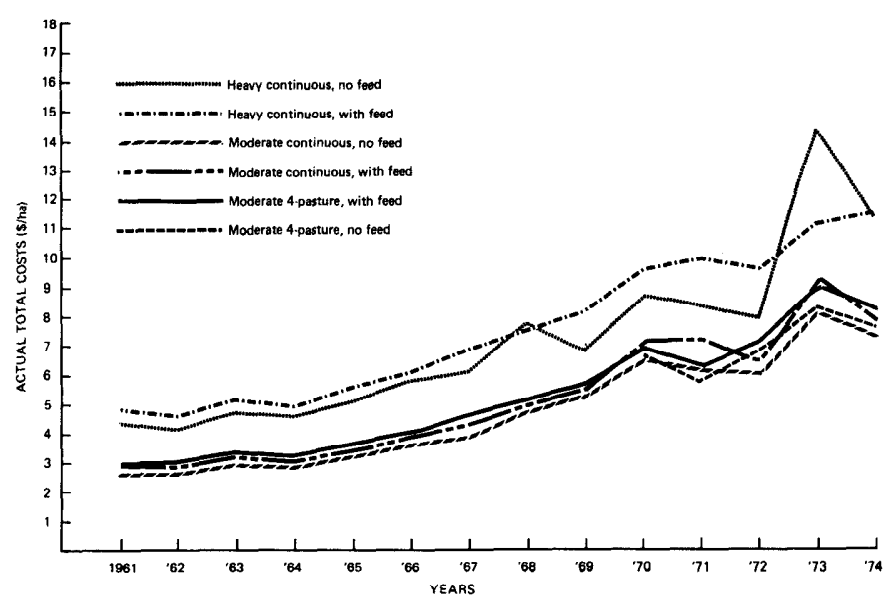

Fig. 3. Actual total costs (\$/ha) from alternative grazing systems on the Texas Experimental Ranch, 1961-1974.

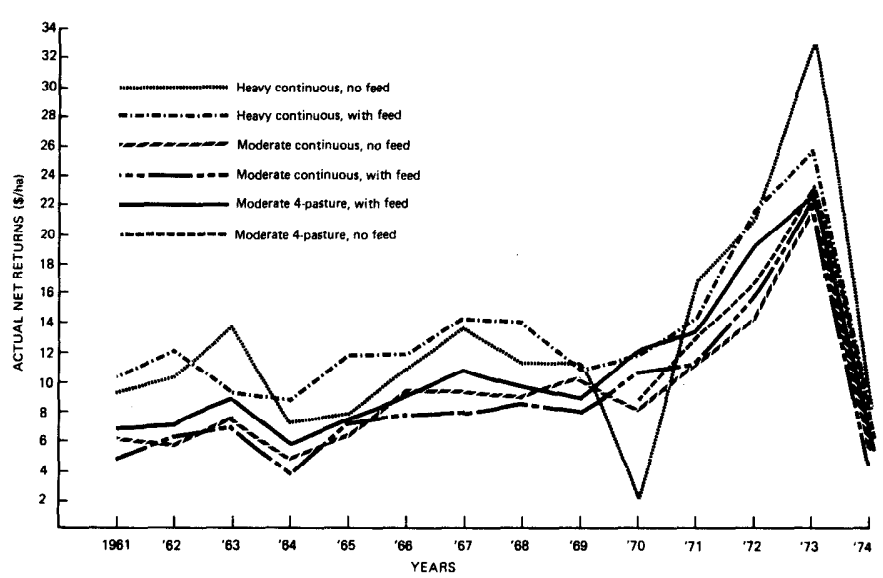

Fig. 4. Actual net returns (\$/ha) from alternative grazing systems on the Texas Experimental Ranch, 1961-1974.

produced significantly greater $(p \leq .05)$ average net income than moderately stocked systems. The four-pasture system was intermediate to the continuously grazed, heavy and moderately stocked systems but was not statistically different when compared to the moderate systems (Table 1).

Supplemental winter feed reduced profits when moderate stocking rates were compared. Supplemental feed increased net returns $4.8 \%$ (1979 dollars) when heavier stocking rates were compared. Thus, supplemental winter feed increased in value as available forage was reduced/animal unit at the heavier rate of stocking (Table 1).

The greatest average net return/ha (1979 dollars) was $\$ 28.53 /$ ha. This return was produced by the heavier stocked continuously grazed herd which received supplemental feed during each winter (HCS). The HCS grazing system produced $49 \%$ more net return than the continuously grazed moderately stocked herd which received supplemental winter feed (MCS), and $27 \%$ more than the moderately stocked, four-pasture system receiving supplemental feed (M4PS). The M4PS produced $17 \%$ greater annual, net returns/ ha (1979 dollars) than a similar yearlong system (Table 1). When the M4PS and the MCS systems were compared, the M4PS produced greater net income in all years (Figure 5).

The HC system produced greater annual net returns than the MC systems. Thus, the economic advantage of heavy stocking was reduced if supplemental winter feed was not provided (Table 1).

The heavier stocked systems also required $45 \%$ to $50 \%$ more

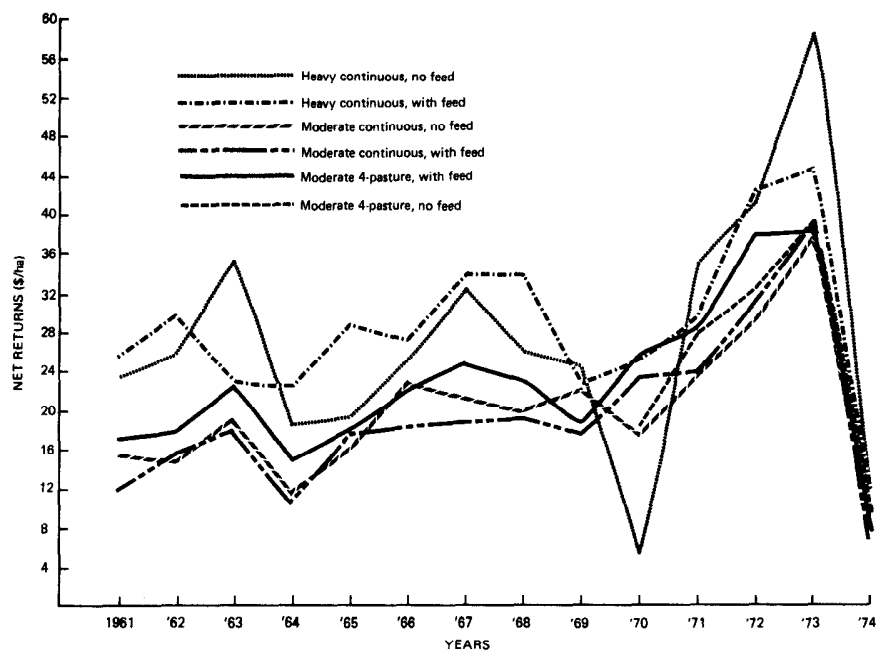

Fig. 5. Net returns (\$/ha, 1979 dollars) from alternative grazing systems on the Texas Experimental Ranch, 1961-1974. 
Table 2. Average annual gross sales, production costs, and net returns ( $\$$ /ha) for six grazing systems on the Texas Rolling Plains, $1970-74$.

\begin{tabular}{|c|c|c|c|c|c|c|}
\hline \multirow[b]{2}{*}{ Grazing systems } & \multirow{2}{*}{$\begin{array}{l}\text { Actual gross } \\
\text { sales }\end{array}$} & \multicolumn{3}{|c|}{ Actual production costs } & \multirow{2}{*}{$\begin{array}{l}\text { Actual net }{ }^{1} \\
\text { returns }\end{array}$} & \multirow{2}{*}{$\begin{array}{l}\text { Net returns } \\
\text { expressed in } \\
1979 \text { dollars }\end{array}$} \\
\hline & & Variable & Fixed & Total & & \\
\hline \multicolumn{7}{|l|}{ Supplemental feed } \\
\hline Heavy, continuous & 26.82 & 5.85 & 4.67 & 10.52 & 16.30 & $30.85 \mathrm{c}$ \\
\hline Moderate, continuous & 20.55 & 4.15 & 3.41 & 7.56 & 12.99 & $24.72 \mathrm{c}$ \\
\hline Moderate, 4-pasture & 22.06 & 4.03 & 3.48 & 7.51 & 14.55 & $27.79 c$ \\
\hline \multicolumn{7}{|l|}{ No supplemental feed } \\
\hline Heavy, continuous & 26.49 & 5.34 & 4.77 & 10.11 & 16.38 & $30.41 \mathrm{c}$ \\
\hline Moderate, continuous & 19.12 & 3.56 & 3.31 & 6.87 & 12.25 & $23.07 \mathrm{c}$ \\
\hline Moderate, 4-pasture & 20.50 & 3.56 & 3.48 & 7.04 & 13.46 & $25.44 \mathrm{c}$ \\
\hline
\end{tabular}

Annual net returns to land and management.

2The wholesale price index was utilized to express the time series in 1979 dollars. Means followed by same letter are not significantly (.05) different.

annual production costs than moderately stocked systems (Table 1). This could indicate the need for ranch operators to increase their use of risk management alternatives because, traditionally, ranch operators have depended upon unused credit capacity to survive economically during adverse economic conditions.

\section{Economic Responses-1970-1974}

In an effort to determine whether economic advantages associated with heavier stocking rates were being maintained over time, results of the last five years of the 14-year period were evaluated. Generally, the heavier stocking rates continued to produce the greatest net returns/ha; however, differences became relatively smaller (Table 2). For example, during the 1961 through 1974 period, the HCS grazing system produced $27 \%$ more net returns (1979 dollars)/ ha than the M4PS system. For the period, 1970 through 1974 , this relative economic advantage had shifted from $27 \%$ to an $11 \%$ advantage over the HCS system (Table 2).

Supplemental winter feeding was marginally profitable for all systems during the last 5 years of the study (Table 2). Average gross sales were approximately the same for continuously grazed, heavily stocked systems. Gross sales were also very similar for continuously grazed, moderately stocked systems (Table 2).

No statistical differences between average annual net incomes were identified ( $p \leq .05$ ) between systems during 1970-1974; whereas, the heavier stocked systems were significantly higher than all other systems tor the period from 1961-1974. Thus, differences between systems were statistically more difficult to identify (fewer observations and greater variability during the period are possible explanations). The fact that there were fewer significant differences between systems is supported by noting that the HCS system produced $11 \%$ more net income than the M4PS during 1970-1974 but $27 \%$ during 1961-1974. Further, the HC system produced $32 \%$ more net income than the MC system in 1970-1974 and $37 \%$ more income during 1961-1974. The four-pasture system produced approximately $11 \%$ more net income during 1970-1974 when compared to moderate, continuous grazing systems. When compared to the period 1961-1974 the difference was 17\% (Table 2). Net incomes/ ha (1979 dollars) averaged $\$ 3.50$ / ha greater during 1970 1974 (Table 2) than during 1961-1974 for comparable systems (Table 1). It is interesting to note that the heavier stocked systems increased approximately $10 \%$ but the moderately stocked systems increased approximately $22 \%$. Thus, economic differences between grazing systems appear to have become less over time.

\section{Income Stability - 1961-1974}

When all five grazing systems were included in the risk-return analysis, the NCS grazing system was optimal. There was not a net income stability adva ntage from combining grazing systems (Table 3). Given the annual variability associated with the HCS system, expected average income would not be lower than $\$ 25.34 /$ ha at the $(p \leq .05)$ level (Table 3 ).

None of the moderately stocked systems contributed to net income stability over the 14-year period when all grazing systems were included in the model. This indicates little, if any negative covariance relationship(s) existed between heavier and moderately stocked systems during 1961-1974. There was no net income stability advantage in combining systems.

When the heavier stocking rates were eliminated from the model, net income fluctuations were minimized with a combination of moderate, continuous without supplemental feed (MC) and the M4PS. At lower annual net income levels $(\$ 21.00 /$ ha) the ratio of the two systems was approximately 1:1 for minimizing risk. As income levels were increased, the MC system was replaced by a M4PS (Table 3). However, an individual would be justified, from a net income stability standpoint, to utilize only the M4PS, Ranch plan 4 , because expected annual net income as well as the lower

Table 3. Annual net income stability characteristics (\$/ha) associated with alternative grazing systems, (1979 dollars), 1961-1974, Texas Rolling Plains.

\begin{tabular}{|c|c|c|c|c|c|c|}
\hline \multirow[b]{2}{*}{ Ranch plan } & \multirow{2}{*}{$\begin{array}{l}\text { Optimal grazing } 1 \\
\text { system(s) }\end{array}$} & \multirow{2}{*}{$\begin{array}{l}\text { Expected net } \\
\text { income }\end{array}$} & \multirow{2}{*}{$\begin{array}{c}\text { Standard deviation }{ }^{2} \\
\text { of net income }\end{array}$} & \multicolumn{3}{|c|}{ Lower net income boundary Confidence Level } \\
\hline & & & & $80 \%$ & $90 \%$ & $95 \%$ \\
\hline \multicolumn{7}{|c|}{ Heavy and moderate stocking } \\
\hline 1 & HCS-100\% ${ }^{3}$ & 28.53 & 6.74 & 26.96 & 26.10 & 25.34 \\
\hline \multicolumn{7}{|c|}{ Moderate stocking only } \\
\hline 1 & $\begin{array}{l}\text { MC-47\% } \\
\text { M4PS-53\% }\end{array}$ & 21.23 & 7.03 & 19.60 & 18.69 & 17.90 \\
\hline 2 & $\begin{array}{l}\text { MC-32\% } \\
\text { M4PS-68\% }\end{array}$ & 21.62 & 7.35 & 19.91 & 18.97 & 18.14 \\
\hline 3 & $\begin{array}{l}\text { MC- } 17 \% \\
\text { M4PS-83\% }\end{array}$ & 22.00 & 7.68 & 20.21 & 19.23 & 18.37 \\
\hline 4 & M4PS- $100 \%$ & 22.45 & 8.15 & 20.56 & 19.51 & 18.59 \\
\hline
\end{tabular}

Grazing systems are defined as follows: $\mathrm{H}=$ heavy, $\mathrm{M}=$ moderate, $\mathrm{C}=$ continuous, $4 \mathrm{P}=$ four pasture and $\mathrm{S}=$ supplemental winter feed.

${ }^{2}$ This estimate is based on a mean absolute deviation.

${ }^{3}$ Percentage of a given ranch in a given grazing system or systems. 
Table 4. Annual net income stability characteristics (\$/ha) of utilizing supplemental feed in the Texas Rolling Plains, (1979 dollars), $1961-1974$.

\begin{tabular}{|c|c|c|c|c|c|}
\hline \multirow[b]{2}{*}{ Grazing system ${ }^{\prime}$} & \multirow{2}{*}{$\begin{array}{l}\text { Expected net } \\
\text { income }\end{array}$} & \multirow{2}{*}{$\begin{array}{c}\text { Standard deviation of } \\
\text { net income }\end{array}$} & \multicolumn{3}{|c|}{ Lower net income boundary Confidence Level } \\
\hline & & & $80 \%$ & $90 \%$ & $95 \%$ \\
\hline $\begin{array}{l}\mathrm{HCS} \\
\mathrm{HC}\end{array}$ & $\begin{array}{l}28.53 \\
27.22\end{array}$ & $\begin{array}{r}6.74 \\
12.14\end{array}$ & $\begin{array}{l}26.96 \\
24.40\end{array}$ & $\begin{array}{l}26.10 \\
22.84\end{array}$ & $\begin{array}{l}25.34 \\
21.47\end{array}$ \\
\hline $\begin{array}{l}\mathrm{MCS} \\
\mathrm{MC}\end{array}$ & $\begin{array}{l}19.17 \\
19.83\end{array}$ & $\begin{array}{l}7.53 \\
6.94\end{array}$ & $\begin{array}{l}17.42 \\
18.24\end{array}$ & $\begin{array}{l}16.45 \\
17.36\end{array}$ & $\begin{array}{l}15.61 \\
16.59\end{array}$ \\
\hline
\end{tabular}

'Grazing systems are defined as follows: $H=$ heavy, $M=$ moderate, $C=$ continuous and $S=$ supplemental winter feed.

2This estimate is based on a mean absolute deviation.

limit of annual net income increased for all three confidence levels when shifting from Ranch plan 1 to 4 (Table 3).

The impact that supplemental winter feed had upon the optimal solution(s) is more identified in Table 4. As discussed earlier, supplemental feeding was marginally profitable for heavier stocking rates, but was not profitable for moderate rates. However, for heavier stocking rates, the standard deviation of annual net income was nearly doubled when supplemental feed was eliminated. Thus, for a $95 \%$ confidence level, average net income could be $\$ 3.87 /$ ha lower because of the increased variability. This indicates that producers who stock heavy would potentially benefit from using supplemental winter feed even if profits were not increased significantly. There were no apparent net income stability benefits of using supplemental feed when moderate stocking rates were utilized (Table 4).

\section{Income Stability, 1970-1974}

In order to test whether the relationships identified over the 14 year period remained relatively constant, a similar analysis was conducted over the last 5 years of the study. When all grazing systems were available, it was determined the HCS was not in the optimal solution as determined in the previous analysis (Table 5). Apparently, negative covariance relationships were present between MCS, MC, and $\mathrm{HC}$ systems at lower annual net income levels (less than $\$ 25.00 / \mathrm{ha}$ ) and between HCS and M4PS systems at greater than $\$ 27.00 /$ ha (Table 5).

Expected net incomes ranged from $\$ 23.95 /$ ha, Ranch plan 1 to $\$ 30.85 /$ ha, Ranch plan 6 . However, the standard deviation of net income ranged from $\$ 9.28 /$ ha to $\$ 15.55 /$ ha. Ranch plan 1 was composed primarily of a MC (53\% of the ranch) and a MCS (45\% of the ranch) system. Ranch plan 6 was composed entirely of the HCS system (Table 5).

Using an $80 \%$ level of confidence a producer would be economi- cally justified in the selection of Ranch plan 6 . However, when $90 \%$ or $95 \%$ confidence levels were utilized, a ranch operator would be justified in selecting up to Ranch plan 4. Beyond Ranch plan 4, an operator would have to decide whether or not the lower net income potential associated with Ranch plan 5 or 6 would be acceptable, given each plan's expected net income (Table 5). An interesting finding was that when compared to the 14-year period, heavier stocking rates had become less stable and/or the moderate stocking rates had become relatively more stable, indicating the importance of long term grazing studies in the evaluation of net income stability characteristics.

When heavier stocking rates were eliminated from the analysis it was determined that a combination of MC and MCS systems resulted in the most stable net income estimates for lower net income levels and at higher net income levels the MCS was replaced by the M4PS system (Table 6). However, a producer would be economically justified in selecting the M4PS system over all other moderate grazing systems evaluated, Ranch plan 4(Table 6).

Supplemental winter feed had a positive impact on the optimal Ranch plans presented in Tables 5 and 6 . In order to more fully evaluate the economic impacts of winter feed during 1970-1974, relevant comparisons are illustrated in Table 7 . As in the previous 14 years of the study, supplemental feed had little, if any impact on average net income. However, when heavier stocking rates were used, standard deviation in net income increased from $\$ 15.55 /$ ha to $\$ 28.95 /$ ha, indicating that the economic value of supplemental feed was annual net income stabilization (Table 7). This stabilizing effect was less for moderate continuous systems but was more pronounced in the four-pasture systems. The significance that supplemental feed had upon the lower net income boundary, using a $95 \%$ confidence interval, could mean that expected net gross

Table 5. Annual net income stability characteristics (S/ha) associated with five grazing systems, 1970-1974 (1979 dollars), Texas Rolling Plains.

\begin{tabular}{|c|c|c|c|c|c|c|}
\hline \multirow[b]{2}{*}{ Ranch plan } & \multirow{2}{*}{$\begin{array}{l}\text { Optimal grazing } 1 \\
\text { system(s) }\end{array}$} & \multirow{2}{*}{$\begin{array}{l}\text { Expected net } \\
\text { income }\end{array}$} & \multirow{2}{*}{$\begin{array}{c}\text { Standard deviation }{ }^{2} \\
\text { net income }\end{array}$} & \multicolumn{3}{|c|}{ Lower net income boundary Confidence Level } \\
\hline & & & & $80 \%$ & $90 \%$ & $95 \%$ \\
\hline 1 & $\begin{array}{l}\text { HC- } 2 \% \%^{3} \\
\text { MC- } 53 \% \\
\text { MCS }-45 \%\end{array}$ & 23.93 & 9.28 & 20.02 & 17.57 & 15.08 \\
\hline 2 & $\begin{array}{l}\mathrm{HC}-14 \% \\
\mathrm{MC}-4 \% \\
\mathrm{MCS}-82 \%\end{array}$ & 25.47 & 9.93 & 21.29 & 18.66 & 16.00 \\
\hline 3 & $\begin{array}{l}\text { HC- } 14 \% \\
\text { MCS-37\% } \\
\text { M4PS-49\% }\end{array}$ & 27.02 & 10.71 & 22.51 & 19.68 & 16.81 \\
\hline 4 & $\begin{array}{l}\text { HC- } 8 \% \\
\text { HCS- } 18 \% \\
\text { M4PS-74\% }\end{array}$ & 28.56 & 11.58 & 23.69 & 20.62 & 17.52 \\
\hline 5 & $\begin{array}{l}\text { HCS-76\% } \\
\text { M4PS-24\% }\end{array}$ & 30.10 & 13.88 & 24.26 & 20.58 & 16.87 \\
\hline 6 & HCS $-100 \%$ & 30.85 & 15.55 & 24.31 & 20.19 & 16.02 \\
\hline
\end{tabular}

Grazing systems are defined as follows: $\mathrm{H}=$ heavy, $\mathrm{M}=$ moderate, $\mathrm{C}=$ continuous, $4 \mathrm{P}=$ four pasture and $\mathrm{S}=$ supplemental winter feed.

2This estimate is based on a mean absolute deviation.

3Percentage of a given ranch in a given grazing system or systems. 
Table 6. Annual net income stability characteristics (\$/ha) associated with moderately stocked grazing systems, 1970-1974 (1979 dollars), Texas Rolling Plains.

\begin{tabular}{|c|c|c|c|c|c|c|}
\hline \multirow[b]{2}{*}{ Ranch plan } & \multirow{2}{*}{$\begin{array}{l}\text { Optimal grazing } 1 \\
\text { system(s) }\end{array}$} & \multirow{2}{*}{$\begin{array}{l}\text { Expected net } \\
\text { income }\end{array}$} & \multirow{2}{*}{$\begin{array}{l}\text { Standard deviation }{ }^{2} \\
\text { of net income }\end{array}$} & \multicolumn{3}{|c|}{ Lower net income boundary Confidence Level } \\
\hline & & & & $80 \%$ & $90 \%$ & $95 \%$ \\
\hline 1 & $\begin{array}{l}\text { MC- } 59 \%^{3} \\
\text { MCS-36\% } \\
\text { M4PS-5\% }\end{array}$ & 23.93 & 9.29 & 20.02 & 17.56 & 15.07 \\
\hline 2 & $\begin{array}{l}\text { MC }-49 \% \\
\text { M4PS-51\% }\end{array}$ & 25.47 & 10.06 & 21.24 & 18.57 & 15.88 \\
\hline 3 & $\begin{array}{l}\text { MC- } 16 \% \\
\text { M4PS-84\% }\end{array}$ & 27.02 & 10.84 & 22.17 & 19.59 & 16.68 \\
\hline 4 & M4PS- $100 \%$ & 27.79 & 11.23 & 23.06 & 20.09 & 17.08 \\
\hline
\end{tabular}

Grazing systems are defined as follows: $\mathrm{H}=$ heavy, $\mathrm{M}=$ moderate, $\mathrm{C}=$ continuous, $4 \mathrm{P}=$ four pasture and $\mathrm{S}=$ supplemental winter feed.

2This estimate is based on a mean absolute deviation.

${ }^{3}$ Percentage of a given ranch in a given grazing system or systems.

incomes could be as low as $\$ 2.81$ / ha for a $\mathrm{HC}$ system compared to $\$ 16.02 /$ ha for a HCS system. It was determined that supplement feed was also important when four-pasture systems were utilized (Table 7)

To summarize the risk a nalysis for 1971-1974, it was evident that considerably more net income variability was present in all systems when compared to 1961-1974. This resulted primarily because of the greater variability in livestock prices and production costs. Other important findings were that: (1) the HCS system did not maintain its annual net income stability advantage; (2) the M4PS had increased in relative economic potential; and (3) the use of winter supplemental feed had become important for increasing annual net income stability, especially for heavier stocking rates. Each of these findings may in part be related to the long-term effects of heavy continuous grazing on forage reserves and forage production.

In most grasslands as grazing intensity increases over long periods of time, the more productive tall and midgrasses are replaced by less productive shortgrasses. Kothmann et al. (1978) reported this general trend at the Texas Experimental Ranch where the two dominant midgrasses, Texas wintergrass (Stipa leucotricha) and sideoats grama (Bouteloua curtipendula), have decreased in frequency in the HC pastures while buffalograss (Buchloe dactyloides) and common curlymesquite (Hilaria belangeri), both shortgrasses, have increased. However, this change was gradual and thus the effect was not particularly evident during the first 8 years of the study. In fact, this change was probably even slower during the first 8 years of the study than would be expected because of the many years of above average annual rainfall.

Rates of stocking were also greater from 1970 through 1974 than previous years (Heitschmidt et al. 1980) and total annual rainfall more erratic (Kothmann et al. 1978). Thus, with the reduced forage production resulting from less productive species, greater rates of stocking and more va riable rainfall patterns, the $\mathrm{HC}$ systems began to display less economic advantages than previously, particularly when winter supplement was not fed. It follows then, that occasional "busts" may become more frequent in the HC systems in future years than through the end of the current study.

This hypothesis was tested in 1975 , although unfortunately no livestock production records were maintained because of required herd changeovers in all systems (Heitschmidt et al. 1980). But because of a rather severe summer and fall drought in 1975, 62\% reduction in the size of the $\mathrm{HC}$ herd was required for a 6-month period from October through March. Similarly, the HCS herd was reduced $30 \%$ while no reductions were required in any of the moderately stocked systems. No reductions in rate of stocking have been required in any system since 1975 .

These required reductions in rates of stocking in 1975 simply emphasize that under heavy rates of stocking occasional "busts" will occur and these will likely occur more frequently at heavy rates of stocking than at moderate rates of stocking. It is doubtful that the total absence of "bust years" from 1961 through 1974 is typical of what a ranchman might expect in this region during the next 15 years.

\section{Conclusions}

Analysis of data from the Texas Experimental Ranch in the Rolling Plains indicate that for the period 1961-1974, continuous, year-long grazing at heavier stocking rates, using supplemental winter feed, produced $27 \%$ more net income/ha than the "next best" alternative, a moderately stocked, four-pasture system. During the last 5 years of the study, the heavier, continuous system, using supplemental winter feed, produced $11 \%$ greater net income/ ha than the "next best" alternative, the moderately stocked, fourpasture system using supplemental feed. This finding indicated that the moderately stocked, four-pasture system was becoming relatively more important as a producer of net income over time.

The use of supplemental winter feed was more profitable when heavier stocking rates were used. However, at best, it was determined to be marginally profitable. The real value of supplemental winter feed was as an anual net income stabilizer, especially so, when stocking rates were higher. At heavier rates, the standard

Table 7. Annual net income (\$/ha) stability characteristics (1979 dollars) of utilizing supplemental feed in the Texas Rolling Plains, $1970-1974$.

\begin{tabular}{|c|c|c|c|c|c|}
\hline \multirow[b]{2}{*}{ Grazing system ${ }^{\prime}$} & \multirow{2}{*}{$\begin{array}{l}\text { Expected net } \\
\text { income }\end{array}$} & \multirow{2}{*}{$\begin{array}{c}\text { Standard deviation of } \\
\text { net income }\end{array}$} & \multicolumn{3}{|c|}{ Lower net income boundary Confidence Level } \\
\hline & & & $80 \%$ & $90 \%$ & $95 \%$ \\
\hline $\begin{array}{l}\mathrm{HCS} \\
\mathrm{HC}\end{array}$ & $\begin{array}{l}30.85 \\
30.41\end{array}$ & $\begin{array}{l}15.55 \\
28.95\end{array}$ & $\begin{array}{l}24.31 \\
18.23\end{array}$ & $\begin{array}{l}20.19 \\
10.56\end{array}$ & $\begin{array}{r}16.02 \\
2.81\end{array}$ \\
\hline $\begin{array}{l}\text { MCS } \\
\mathrm{MC}\end{array}$ & $\begin{array}{l}24.72 \\
23.07\end{array}$ & $\begin{array}{r}9.70 \\
10.98\end{array}$ & $\begin{array}{l}20.64 \\
18.45\end{array}$ & $\begin{array}{l}18.07 \\
15.54\end{array}$ & $\begin{array}{l}15.47 \\
12.60\end{array}$ \\
\hline $\begin{array}{l}\text { M4PS } \\
\text { M4P }\end{array}$ & $\begin{array}{l}27.79 \\
25.44\end{array}$ & $\begin{array}{l}11.23 \\
18.75\end{array}$ & $\begin{array}{l}23.06 \\
17.55\end{array}$ & $\begin{array}{l}20.09 \\
12.59\end{array}$ & $\begin{array}{r}17.08 \\
7.56\end{array}$ \\
\hline
\end{tabular}

'Grazing systems are defined as follows: $\mathrm{H}=$ heavy, $\mathrm{M}=, \mathrm{C}=$ continuous and $\mathrm{S}=$ supplemental winter feed.

${ }^{2}$ This estimate is based on a mean absolute deviation. 
deviation of net income was approximately doubled when supplemental feed was not provided.

For the period 1961-1974, annual net income stability was maximized by using supplemental winter feed with a heavier stocked, continuous, year-long grazing system. No other combinations of the five grazing systems provided any additional annual net income stability value. When the heavier stocking rates were eliminated from the analysis, there was a net income stability effect by combining a four-pasture system, with supplemental feed with a continuous, yearlong system, without winter feed.

When the period 1970-1974 was evaluated, the heavier stocked, continuous system with supplemental feed was determined to have lost its net income stabilizing potential. The heavier stocked system was replaced, at less than maximum income levels, by moderate stocking, continuous, and four-pasture combinations. This indicated that the moderate, four-pasture system was apparently becoming relatively more important as a net income stabilizer the longer the grazing systems were evaluated. This finding is supported by Kothmann, et al. (1978), who reported significant decreases in the climax vegetation over time as a result of heavier grazing on the Texas Experimental Ranch.

Ranch operators in the Rolling Plains may need to adopt more risk management techniques to counter the increasing economic instability of recent times caused by varying livestock prices, as well as relatively rapid increases in production costs. Further study will be required to evaluate risk management and alternative net income producing strategies. For example, the maintenance of weaned animals in a vertical integration program, adoption of alternative credit management options or adoption of other marketing alternatives, such as the futures market or forward contract, may be possible alternatives.

It is evident that optimal ranch organizations may vary. Variability may be explained by observing differences in risk-return situations and individual preferences. Risk analysis may have considerable potential as part of a "traditional" profit maximizing economic analysis, provided adequate data exists.

\section{Literature Cited}

Hazell, P.B.R. 1971. A linear alternative to quadratic and semivariance programming for farm planning under uncertainty. Amer. J. of Agr. Econ. 53:53-62.
Heitschmidt, R.K., M.M. Kothmann, and W.K. Rawlins. 1982. Cow-calf response to stocking rates, grazing systems and winter supplement over a 15 year period at the Texas Experimental Ranch. J. Range Manage. 35:204-210

Hopkin, J.A., P.J. Barry, and C.B. Baker. 1973. Financial management in agriculture. Interstate Printers and Publishers, Inc. Danville, Ill. 459 p.

Huss, D.L., and J.V. Allen .1969. Livestock and profitability comparisons of various grazing systems, Texas Range station. Tex. Agr. Exp. Sta. Bull. 1089. $14 \mathrm{p}$.

Kothmann, M.M., G.W. Mathis, Wm. J. Waldrip. 1978. Rangeland vegetation of the Texas Rolling Plains: response to grazing management and weather. Proc. Ist Internat. Rangeland Cong., Denver, Colo. p. 606-609.

Kothmann, M.M., G.W. Mathis, and Wm. J. Waldrip. 1971. Cow-calf response to stocking rates and grazing systems on native range. J. Range Manage. 24:100-105.

Kothmann, M.M., G.W. Mathis, P.T. Marion, and Wm. J. Waldrip. 1970. Livestock production and economic returns from grazing treatments on the Texas Experimental Ranch. Tex. Agr. Exp. Sta. Bull. 1100. 39 p.

Markowitz, H.M. 1959. Portfolio selection. Yale Univ. Press, New Haven, Conn. 351 p.

Merrill, L.B. 1954. A variation of deferred rotation grazing for use under southwest range conditions. J. of Range Manage., Vol. 7:152-154.

Merrill, L.B., and C.A. Taylor. 1975. Economics of brush control practices under four-pasture rotational grazing. In: Rangeland resources resea rch 1971-1974. Tex. Agr. Exp. Sta. Consol. PR-3341. 70 p.

Reardon, P.O., and R.E. Whitson. 1980. Economic comparison of grazing systems in the Rio Grande Plain of Texas. Ann. Mtg. Soc. Range Manage. 33 (Abstr.):36.

Texas Agricultural Extension Service. 1980. Cow-calf production, Texas Rolling Plains, estimated costs and returns per cow. Livestock budgets.

U.S. Dep. Agr. 1980. Agricultural finance datebook. Div. of Res. and Stat., Fed. Reserve System. Washington, D.C.

U.S. Dèp. Agr. 1979. Prices paid by farmers: index numbers by groups of commodities, U.S. 1965-1978. Agricultural Statistics. 603 p.

U.S. Dep. Agr. 1978. Farm labor. Crop Reporting Board. Eco. Stat. and Coop Ser. Washington, D.C.

U.S. Dep. Agr. 1975. All commodities bought for use in production. U.S. Agr. Statistics. 619 p.

U.S. Dep. Agr. 1974. Livestock detailed quotations. Consumer and marketing services. Livestock division. Amarillo; Texas Market 1960-1974.

U.S. Dep. Commerce. 1979. Statistical abstract of the U.S. wholesale price index, all commodities. Bureau of Census. $1048 \mathrm{p}$.

Whitson, R.E. 1975. Ranch decision-making under uncertainty-an illustration. J. Range Manage. 28:267-270.

\section{Membership in the Society for Range Management. . .}

is open to those engaged in or interested in the study. management, or use of range ecosystems and the intelligent use of all range resources

includes research scientists, ranchers, governmental agency administrators and technical personnel. teachers, students, and people from the business community

provides members with two publications-one oriented to research (Journal of Range Management) and the other oriented to practical resource management (Rangelands) offers opportunities for face-to-face exchange of ideas at local, national, and intemational meetings of the Society.

Dues vary according to type of membership and geographical section. For application forms and additional information, contact the:

Executive Secretary

Society for Range Management

2760 West Fifth Avenue

Denver, Colorado 80204

(303) $571-0174$ 